\title{
THE SEVENTH BRITISH COMMONWEALTH FORESTRY CONFERENCE ${ }^{1}$
}

\author{
By J. H. JENKINS
}

Congenial company, good planning and organization by the host countries, interesting discussion, and encouraging evidence of progress in Commonwealth forestry, were the dominant features of the Seventh British Commonwealth Forestry Conference which was held in Australia and New Zealand from August 26 to October 10, 1957.

In addition to being head of the Canadian Delegation and a Federal Government representative, I also represented the Canadian Institute of Forestry. Other members of the Canadian Delegation were H. W. Beall, Chief, Forestry Operations Division, Federal Forestry Branch; C. D. Orchard, Deputy Minister of Forests, British Columbia; Professor R. W. Wellwood, University of British Columbia; B. M. McGoogan, Forest Biology Division, Federal Department of Agriculture; C. D. Schultz, Consulting Forester, Vancouver (representing Canadian Forestry Association); and N. R. Dusting, B.C. Lumber Manufacturers' Association.

In addition to representation of 18 British Commonwealth countries by 78 delegates, representatives from the U.S. Forest Service and from F.A.O. attended as guest delegates. The Chairman of the Conference was G. J. Rodger, Director General, Forestry and Timber Bureau, Australia, and the Deputy Chairman was A. R. Entrican, Director, New Zealand Forestry Service.

Definite progress in the various fields of Commonwealth forestry was rported to have taken place in the member countries since the last reports were presented to the Sixth B.C.F.C. held in Ottawa in 1952. However, in reporing progress, the delegates generally stressed the high volume of work yet to be done. They observed that time was running out and that further delays could easily result in great economic difficulties.

Worthy of note, also, were the reports from a number of smaller colonies which showed that considerable sums were being expended by the British Treasury in efforts to improve the forests in these countries. It was evident, both from reports and discussions within and outside the Conference, that most Commonwealth countries have now established sound and dynamic forest policies which are accepted as integral parts of their economic and political development.

The spectre of deforestation was many times present during Conference discussions. Time and again it was repeated that to meet future timber requirements it is essential that policies be immediately adopted to ensure orderly management of the remaining forests and that vigorous restocking be undertaken. It was emphasized that the often reiterated policy of "sustained yield" was not enough and that greater stress should be given to the principle of "sustained optimum yield".

${ }^{2}$ A contribution from the Forest Products Laboratories of Canada, a Division of the Forestry Branch, Department of Northern Affairs and National Resources. 
Since, also, it was unrealistic to assume or expect that every country could attempt to become self-supporting in its requirements for forest products, while at the same time maintaining national development in the best economic sense, it also became evident, and of extreme importance, that exporting countries should develop their timber resources and utilize present stocks through the application of informed long-term and economic exploitation.

The importance of the forest is not limited to the service it renders in the supply of wood raw material. It plays important roles in other fields. In many countries the importance of forests on areas reserved for water catchment must receive primary consideration. In fact, throughout the Commonwealth large tracts of land have been set aside as catchment areas and in many countries the search continues for additional areas suited to this purpose. The value of the forests in these lands in preventing erosion and providing for a well regulated flow to feed a stream is generally well known. However, opinion of the Conference was that such forests should be under adequate sustained yield management so that there would be provided the vital protection essential to prevent destruction by fire and disease while at the same time providing a valuable source of timber supply. This is, of course, a realistic approach; whatever the primary function, forests under sound management perform that function better while also assuring a maximum yield of wood substance.

There have been great developments of softwood plantation throughout the Commonwealth, and in such countries as Australia, New Zealand, South Africa, and the United Kingdom harvesting of useful timber from these areas is steadily increasing. The Conference stressed the need for constant vigilence against soil deterioration on planted areas and reaffirmed the importance of preserving and maintaining the productivity of the soil in which crops of trees are grown. Highly significant and promising results have been achieved in the fields of forest tree breeding and seed provenance studies in respect of superior tree and stem devlopment as well as desirable wood growth characteristics. There are outstanding opportunities in these fields for large-scale improvement of growing stock and for the provision of forest products most suited to the needs of Commonwealth countries. It was noted, also, that the effect of unfavorable climatic conditions and the importance of reduction of disease and of insect attack must be kept constantly in mind.

There was agreement that there is a growing and encouraging emphasis by the wood-using industries on sustained yield management as being essential to their long-term stability and prosperity. In turn, such a policy must depend on full and integrated use of all forest wood substance, kept in proper relation to the productive capacity of the forests. Considerable progress has been made in forest management, but many problems remain, such as the difficulties encountered in obtaining a planned and economic use of large volumes of small size thinning materials, the removal of which is essential for silvicultural reasons.

It was agreed that an important principle of management should be the development of a program which, from the start, would give attention to the building up of a normal series of age classes; of early construction and development of access roads and protection facilities; and of securing stability of 
employment for the forest labor involved. Likewise, there is need for improvements in tree and stand quality when stocking and restocking of forest areas becomes necessary to obtain the maximum use of available land.

As has been customary at B.C.F.C. Conferences, one of the outstanding features was the opportunity provided to study the forests and forest products industries of the host country. At this Conference all aspects of forestry and forest utilization in the various states of the Commonwealth of Australia and in the Dominion of New Zealand were presented to the delegates by way of visits to selected forests and woodworking plans, by beneficial association with senior members of the various forest services in those countries, by attending the Conference as delegates and through talks with the many Australian and New Zealand foresters with whom we met during the extended tours.

Compared with Canada, the total forest areas of Australia and New Zealand are small (see Table I). Australia and New Zealand were grouped as joint hosts because of their geographical proximity. There is, however, a marked difference in their utilization policies, practices and problems.

In Australia alone, surprising differences were noted between the forests and forestry practices and policies in the various States visited.

TABLE I

Comparison of Australia, New Zealand and Canada

\begin{tabular}{|c|c|c|c|c|c|c|}
\hline Country & $\begin{array}{c}\text { Popu- } \\
\text { lation } \\
\text { Million }\end{array}$ & $\begin{array}{c}\text { Total } \\
\text { Land } \\
\text { M. sq. m. }\end{array}$ & $\begin{array}{c}\text { Forests } \\
\text { M. sq. m. }\end{array}$ & $\begin{array}{c}\text { Forest } \\
\text { Land } \\
\%\end{array}$ & $\begin{array}{c}\text { Volume Stan } \\
\text { in Exploita } \\
\text { (Million } \\
\text { Softwood }\end{array}$ & $\begin{array}{l}\text { ding Timber } \\
\text { ble Forest } \\
\text { cu. ft.) } \\
\text { Hardwood }\end{array}$ \\
\hline $\begin{array}{l}\text { Australia } \\
\text { New Zealand } \\
\text { Canada }\end{array}$ & $\begin{array}{r}9.3 \\
2.2 \\
15.6\end{array}$ & $\begin{array}{r}2,970 \\
102 \\
3,560\end{array}$ & $\begin{array}{c}187 \\
25 \\
1,621 \\
2 \text { per cent } \\
\text { roductive) }\end{array}$ & $\begin{array}{r}6.3 \\
24.6 \\
46.0\end{array}$ & $\begin{array}{r}1,290 \\
4,884 \\
273,598\end{array}$ & $\begin{array}{r}16,602 \\
627 \\
89,667\end{array}$ \\
\hline
\end{tabular}

Hardwoods are the dominant trees of the Australian forests and are composed of a very large number of species, most of which are of the genus. Eucalyptus. Groups of these eucalyptus are commercially known as gum bark, stringy bark, or iron bark according to their bark characteristics. Some of the species are particularly durable in the ground and, therefore, do not require preservative treatment when used as posts or piling. The species known as "turpentine" resists marine borer attack and will give 40 to 50 years service when used as untreated piling. Other species, such as tallow wood, make excellent flooring. However, these eucalyptus are hard, dense and inclined to warp unless carefully seasoned. They are, therefore, difficult to work and not as well suited for house framing purposes as softwood lumber. Pulp is now being produced from eucalyptus, but the addition of softwood pulp is necessary where paper strength is important.

In Australia great attention has been paid to plantation forestry, par- 
ticularly to thinning and pruning. The effect of pruning in improving the quality of the timber produced was very marked and it is considered good practice to combine pruning and thinning. South Australia was of special interest because this State, with negligible indigenous forests, has undertaken an ambitious program of plantations and has established three State-operated sawmills for the utilization of the timber from these plantations. This timber is now sufficiently large to produce good quality 1" $\times$ 6" pine flooring. These State sawmills, specially designed for the manufacture of small logs, use combinations of gang saws, double-circular headsaws, and band headrigs. These and other mills, specially designed for the cutting of plantation stock, are of interest to Eastern Canada where spruce logs of small diameter are being manufactured.

Of particular interest in New Zealand forestry are the extensive plantings of exotic softwoods, mainly Pinus radiata, with some Douglas fir plantings having been made during the past 35 years. During the period from 1923-1936, there was an "afforestation stock selling boom", during which 376,000 acres were planted. It is estimated that there are now about 925,000 acres in plantation, some 50 per cent are radiata pine, with ponderosa pine, Corsican pine, and Douglas fir being the other three main species. While there have been failures, due to selection of poor species or bad sites, the growth and vigor of the plantations are impressive. During the depression and the last war, thinning and pruning of the young trees were neglected and as a result the forests look untidy, with dead branches on the lower half of vigorous trees. However, the lumber and pulp products now being manufactured in the integrated utilization of these forests are impressive. It is estimated that the annual growth in the State plantations alone is about 65 million cu. ft.-i.e., quantitatively the position of exotic forestry in New Zealand is basically sound, but qualitatively the forests leave much to be desired. Steps have been taken to improve the quality of these plantations and to get cleaner stock and better distribution of age classes. However, the dominating impression of New Zealand forestry is the attention paid to utilization of the plantations by the establishment of largescale, integrated operations comprising sawmills, pulp mills and board mills. This integration requires heavy capital which can only be justified when there are adequate supplies of timber and an assured market.

As a preliminiary to the main conference, Professor Wellwood and I attended the Forest Products Research Conference held in Melbourne from August 12th to 16 th. Following the pattern established in Ottawa, when the first Forest Products Research Conference was held immediately prior to the 6th B.C.F.C. in 1952, special attention was paid to studying the forest products and utilization research facilities and programs of the host countries. At this Melbourne Conference details regarding their organization and research policy were supplied by the Division of Forest Products Research, CSIRO, by the heads of the Wood Technology or Wood Utilization Divisions of the New South Wales and Queensland Forest Services, and by the forest products research officers of the New Zealand Forest Service. The Translation Exchange between forest products research organizations, with its provision for notification of "intention to translate" has been extremely successful since its initiation at the Ottawa Forest Products Conference in 1952. It has eliminated duplication of translations and has made them more freely available to the 
research workers concerned. As participants, during the past five years, the Forest Products Laboratories of Canada have arranged for the translation and circulation of 129 papers and reports and have received in exchange 430 translations from other Commonwealth laboratories and from Madison, U.S.A.

Those attending were unanimous in the view that this Melbourne Conference had been a most valuable one, enabling an exchange of ideas and improvement in the co-ordination of research which would not otherwise have been possible. This clearing up of subjects of specialized forest products interest enabled the forest products delegates to give their undivided attention to the subsequent main conference and to those fields of work of mutual interest to the forester and the forest products research worker.

On termination of the B.C.F.C. meetings in October, I travelled to the Philippines and Japan and there observed the forest products research facilities and studied the inter-relationship between the supply of mahogany (lauan) logs from the Philippines and the developments in the plywood industry of Japan and the Philippines and their possible effect on Canadian trade and industry.

Attendance at this Commonwealth Forestry Conference and the subsequent visits were of special value in providing opportunity for discussion and observation of forestry policy and of the forest industries in the four countries visited. The developments in the forests of these countries and the growing potential and productive capacity of their industries, are such as to produce an even greater realization of the need for the continued progress in Canada of the practice of forestry and in the development of our forest-based industries. This is essential if they are to retain ascendancy in home markets and maintain their competitive position in world trade. What I saw during this 32,000-mile trip made still firmer my conviction of the value and indispensability of research. 